\title{
Preface - utopian myths and a dystopian present
}

Let's all get together and have a good hate ${ }^{1}$

These are not utterances from the Ghost of Christmas Past.

Not premonitions - not wishful thinking.

The assertions on which the argument rests are ineffable, for one reason looming in the world's short-term future.

Global warming - climate change.

For all its impending tragedy, there is good to come of it. Whereas the global powers, political and commercial, were all too ready to tackle the recent COVID-19 pandemic, these powers have shown great reluctance to short-circuit the warming of the planet before time runs short. Unlike even shambolic pandemic control, the recalcitrant reluctance of global powers, political and commercial, to short-circuit the warming of the planet means for climate change there will be no miracle cure won from the work of dedicated scientists and profited by the 'pharma' Mafia. The climate is irreversibly changing towards disaster, and before that is complete, the epoch of neoliberal mega-capitalism and distorted populist political disempowerment will crumble. Along with these inevitabilities, there is much to ponder about the future of law and the social good it has a capacity to sustain, or side-step.

It is the moment of the end of neoliberalism and the rickety collapse of liberal democracy. The seeds for the demise of both can be found simply and clearly in the parlous state of private property rights. ${ }^{2}$ Liberal democracy, as with its neoliberal economic crutches, is a contradiction in terms. In its early incarnations, classical British libertarian thought was grounded in the rights of the individual, property rights being paramount. A true liberal libertarian was a man in control of himself and his possessions, human and material. His tolerated form of democracy was a meeting of similar minds representative only

\footnotetext{
1 G. Orwell (1950) Coming up for Air, New York: Houghton Mifflin Harcourt Publishing.

2 M. Findlay (2015) Property, Labour and Legal Regulation; Dignity or Dependence?, Cheltenham, UK and Northampton, MA, USA: Edward Elgar.
}

viii 
of interests founded in dominion, and inclusive of no-one without a designated property cache. 'People' were other rights-bearing men. 'Society' was nothing besides an agreement among the privileged to respect each other's property rights.

I wrote these brave declarations before the COVID-19 pandemic. Living in a world where crisis unpreparedness has bumbled the unfolding human tragedy, I have even greater confidence that the prevailing global economic order is failing, with the frail renderings of liberal democracy regularly reverting to confused and sometimes incompetent political self-interest in response to the pandemic, suggesting no political platform for what is to come. My views in 2013 are prescient:

health policy priorities are subject to the interest of trade and trading partners and not vice versa ... If one considers health governance as a consequence of global pandemics, and then the contribution of health policy in states of pandemic as compared to health policy diminution to the interests of trade when the fear of pandemics is distant, the pragmatist approach to global health concerns in the arena of governance is all too apparent. In the pandemic wave, health regulation is responsive and the impact it has on global governance is to emphasise mutual social consequences. Lifting the risks of pandemics and returning the economic priority of trade and health concerns to mutualized priorities in an equitable social context unfortunately more commonly and universally retreats in the modernisation global governance mix ... ${ }^{3}$

The pandemic fear gives impetus for progressing shared risk to a shared fate of regulatory mutuality. ${ }^{4}$ Yet sociability is fast being lost in the materialist, pragmatic panic back to a privileged planet normal. The shock waves of social disruption, however, go much deeper than immediate concerns for personal health or their abatement, and economic concerns for averting financial Armageddon. The stealthy advance of climate change, universally more deadly than any virus, continues without even a touch of the same urgent if chaotic resolve with which nation states determine pandemic control. As climate change tipping points are approached and past, the savage social and economic inequality that defines global wealth creation will no longer be papered over by populism or the petrified promises of another day's dirt wage for the diminishing labour market.

Of course, taken to its essentialist core, the consequences of a neoliberal world view have become so uber discriminatory that even from the individu-

3 M. Findlay (2013) Contemporary Challenges in Regulating Global Crises, Basingstoke: Palgrave Macmillan, pp. 161-2. (2013). 
alist beneficiaries modifications are required, not so much for the welfare of mankind, but to ensure the orderly progression of the status quo. ${ }^{5} \mathrm{Up}$ until the 1960 s, a gentler form of liberalism protected the exclusivity of private rights at a social price from states in retreat; public education, housing and health, social welfare, trade unions, and worst of all for a neolib, taxes.

At the time of the Washington Consensus, ${ }^{6}$ moderate liberals were endeavouring to make democracy safe for property. However, radically self-interested businessmen, economists and politicians ended up dragging any such thinking to the minimalist right, as they lobbied for the eventual extreme transformation of liberal democracy into the servitude of discriminatory neoliberal economics.

The genesis of this book was the initial election of Donald Trump as president of the United States of America. It will be completed before his bid for re-election hopefully fails. How could an event like that and a person such as Trump stimulate the discussions to follow? The answer is simple. Like his current attempts to sheet responsibility for the virus back to China, deflecting attention from the incompetence of his administration's response, ${ }^{7}$ in his first campaign rhetoric Trump blamed globalisation, among a host of other usual suspects that populists target, for the suffering of middle America. This lie had to be answered.

In addition, ruling as Trump does through anxiety governance (see Chapter 3), legal regulation has been demeaned in favour of administrative fiat attacking immigrant scapegoats, transgender personnel in the military, abortion rights, and secular schooling ... the list goes on. Against this background, the original purposes of the book were confined: to rehabilitate an understanding of globalisation as an answer to populist discrimination and exclusion; and in doing so, lay blame for massive social inequality where it should lie, namely with neoliberal economics and failing liberal democracy; as well as to speculate on the role of law and legal regulation in possible orderly transitions to some future economic and social order. Much has changed since those early intentions.

Before charting a revised course, it is necessary to revert to the essential critical metaphors of autocratic populism and ask a question of how they relate. If we avoid conflating liberalism and democracy, will that diminish the threat

5 G. Smith (2014) 'Self-interest and Social Order in Classical Liberalism: Shaftesbury', Libertarianism https:/www.libertarianism.org/columns/self-interest -social-order-classical-liberalism-shaftesbury (accessed 1 June 2020).

6 J. Stiglitz (2002) 'Challenging the Washington Consensus', https://www8 .gsb.columbia.edu/faculty/jstiglitz/sites/jstiglitz/files/2003_Challenging_Washington Consensus.pdf (accessed 1 June 2020).

7 Recall his personal suggestion that people should inject bleach to ward off the virus. 
to both forms of governance and economy which the separate disestablishing of liberal democracy and neoliberalism predicts? Unfortunately, it will not. ${ }^{8}$ Without recognizing and prioritising the incipient influence of shared humane virtue, so important in addressing our responsibility for the planet, representative democracy and even socially responsible economics can become tools of tyranny. Preceding egoist individualism, liberals would offer in restraint of individualist excess what Tocqueville referred to as 'well-meaning men' and 'missionaries of truth', but as he saw it, without a population 'educated to democracy, democracy fast becomes "illiberal". 9 Democracy has never been an egalitarian venture from the agora of ancient Athens, to Capitol Hill. The problem with our prevailing political and economic models bastardised as they have become, is elitism - not as the populist chant, but with their project of rationality above humanity.

The intentions for this book have progressed. The rehabilitation of globalisation remains a platform for rejecting the neoliberal/autocratic populist assault on shared human virtue. Law remains a binding theme, and a critical reactionary force to be contradicted, in the hope for socially bonded transition. Largely jettisoned is the earlier interest in highlighting the radical revision of legal agency, law firms and legal services from monetised commodities to spaces for communal benefit. ${ }^{10}$ Replacing this empirical examination, is a discussion of AI and big data's assault on the legal/professional ecosystem and the battle between wealth creation and access to justice. ${ }^{11}$ Thematically aligned with this new direction of thinking is a second case study of participatory self-regulation in platform economies. Both are provided as examples of the struggle between neoliberal imperatives behind technological dehumanism, and the opportunities for humane counter-movements in which the just normative influence of law is possible. Social justice versus individualist betterment resonates throughout the treatment of these preferred case-studies. The interest in legal service delivery in crisis is retained by connecting it also with the influence of $\mathrm{AI}$ and big data.

8 H. Rosenblatt (2018) 'Liberal Democracy is in Crisis, But Do We...Know What It Is?', The Guardian https://www.theguardian.com/commentisfree/2018/may/ 27/liberal-democracy-history-us-politics (accessed 1 June 2020).

9 A. de Tocqueville (2000) Democracy in America, edited and translated by $\mathrm{H}$. Mansfield and D. Winthrop, Chicago: University of Chicago Press.

10 These ideas have been introduced in M. Findlay (2017) Law's Regulatory Relevance: Property Power and Market Economies, Cheltenham, UK and Northampton, Mass., USA: Edward Elgar.

11 A reason for this shift in emphasis is the recognition that AI and big data, more than any phenomena defining our present times, have the potential to drag out the demise of neoliberalism or to hasten its end depending on the motivations behind their application. 
In North world cities shattered by this virus, there remains a quaint and cruel debate about the state's duty to protect the citizen through enforced social distancing, and the intrusion this represents into freedoms of movement and association. Yet, these reflections on rights and liberties should be qualified against economic conditions like the sanguine realization that 90 per cent of Singapore's infection surge is made up of migrant workers initially quarantined in warehouse conditions to stop the spread to outside communities. In the face of this harsh reality of mass incubation liberty and individual dignity are a chimera available to be debated by those on the richer side of the wealth divide.

In an article entitled 'Neoliberalism: The idea that swallowed the world', ${ }^{12}$ the author identifies neoliberalism as 'a way of reordering social reality, of rethinking our status as individuals'. It is the centrality of individualism, soon distorted into egoism (veiled in rationality or otherwise), chauvinism and essentialism, which denies any relevance in some Greco imagining of representative democracy. Authoritarian populism and egoist economics are as illiberal as they are exclusive, and will be their own downfall when the necessities for shared risk to shared fate are impossible to ignore.

The analysis to follow is a layered engagement with several pernicious mythologies primarily underpinning neoliberalism and its political and economic governance. First, there is the unashamed and largely untested dogma from the populist right and the dissenting left that globalisation is the enemy. A New York Times report, under the banner 'Russia Looks to Exploit Turbulence with Trump', ${ }^{13}$ referred to Russian president Putin's long held desire to 'crack the liberal Western order both as a competitor and as a champion of an alternative illiberal model'. The article talked of a political agenda which creates turmoil and exploits the resulting opportunities. It will be suggested throughout this text that the neoliberal economic dominion is successfully undermining classical liberal market moralities and values, without needing nefarious external assistance.

More than rubbishing neoliberalism, the argument to follow goes deeper into its relationship with law and the consequences for law in this time of turbulence. Law has been a handmaiden for neoliberalism through its guardianship of private property. As property rights are epidemically assailed, law's

12 S. Metcalf (2017) 'Neoliberalism: The Idea That Swallowed the World', The Guardian https://www.theguardian.com/news/2017/aug/18/neoliberalism-the-idea -that-changed-the-world (accessed 1 June 2020).

13 N. MacFarquhar (2017) 'Russia Looks to Exploit Turbulence with Trump', New York Times https://www.nytimes.com/2017/02/27/world/europe/russia-looks-to -exploit-white-house-turbulence-analysts-say.html (accessed 1 June 2020). 
utility for the dominant economic frame wanes. ${ }^{14}$ What then is the future for law in global transition?

For the myriads that are angry at globalisation and feel cheated out of its espoused benefits, they do not require Putin to destabilise the status quo. Disruptive economies, a euphemism for the wholesale scrapping of social security and the welfare net, are doing a good job at making middle class materialist certainties a thing of the past (see Chapter 7).

They notice that the attempt to squeeze the last cent of profit out of any operation has also squeezed the last trace of sentiment out of what passes for human interaction. They see that technology serves relentless efficiency, and somewhere in that efficiency life gets joyless and existence precarious. They note that good unions, retirement benefits, manufacturing jobs, overtime and health care get eliminated or curtailed in the pursuit of that last cent ... they know if something goes wrong with the rigged system the losses will get 'socialised.' Regular schmucks who work a shift will pay while insiders walk away. That's how things have been since the 21 st century began. The fix is always in. ${ }^{15}$

The second myth is that migration forms the major contemporary challenge to job security and national identity; rather than what fuels North/South market imperialism through the devaluation of labour courtesy of the tyranny of poverty. ${ }^{16}$ In a world that has paradoxically staked its economic development on neoliberal articles of faith, such as the free movement of labour and free trade, the global governance pendulum has recently swung in the opposite direction. Protectionism fuelled by xenophobia has set in and threatens to proliferate and polarise closed communities of distrust. Political revisions in the hegemon, demanded by those who feel cheated by globalisation and ignored by political elites, are producing reactionary dualities along old fault lines of race, class and gender. An anti-intellectual backlash is further severing social bonds which secular democracy and classical liberalism assumed to be unassailable. For instance, populist wisdom about pandemic health care and protective responses has often preferred to deride science as some conspirator in efforts to deny freedom, instead advocating untested, often extreme primitive remedial interventions. Such rejection of specialist knowledge is consistent with prioritising economic over social lifestyles, supported by subsidised professional interventions, to the detriment of communal foundations like the supporting networks of extended families.

Findlay (2017).

15 R. Cohen (2017) 'The Madness of Crowds', New York Times https://www .nytimes.com/2017/02/28/opinion/the-madness-of-crowds.html (accessed 1 June 2020).

16 See Findlay (2015). 
The third myth is that a return to protectionism will make exploitative and atrophying economies 'great again', in an inevitable economic reality of no growth and AI dispossession. ${ }^{17}$ An example of the nationalist irrational over the economic rational is how the 'Leave' momentum that narrowly got the Brexit referendum in the UK over the line was driven by a few passionately anti-European politicians capitalising on the irrational anxieties of British nationalists who had their roots in world war phobias, rather than the realities of contemporary labour dependencies.

Re-nationalism and re-tribalism threaten to open up cold wars on new fronts, trade wars over old protectionist dualities, prioritised national interests above global obligations, and the break-up of powerful market and political unions in the name of autonomy and sovereignty. Refugees are being turned back along with the tide of economic and social migration. Historical divides over religion and race are redressed in the guise of national security to justify global social exclusion. In the USA, Islamic fundamentalism is demonised and warred against, while white supremacist violence is apologised for and diminished to individual phobia.

The fourth myth is that neoliberal economic individualism offers opportunities to all who want to work, and welfarism retards the realisation of wealth creation for those who bear the tax burden. In an IMF debate over neoliberalism in 2016, economists who might otherwise have ascribed to the economic model exposed the socially destructive neoliberal agenda of deregulating world economies, forming open markets to trade and capital, and demanding that governments shrink themselves through privatisation and austerity. 'Instead of delivering growth, some neoliberal policies have increased inequality, in turn jeopardising durable expansion.' ${ }^{18}$ Returning to 'The Idea that Swallowed the World' and its retort to the meritocracy de-culturalised and de-historisised message:

You see how pervasively we are now urged to think of ourselves as proprietors of our own talents and initiative, how glibly we are told to compete and adapt. You see the extent to which a language formerly confined to chalkboard simulations describing commodity markets (competition, perfect information, rational behaviour) has been applied to all society, until it has invaded the grit of our personal lives, and how the attitude of the salesman has become enmeshed in all modes of self-expression. ${ }^{19}$

17 By this is meant the capacity for AI assisted technologies to ravage wage labour (see Chapter 7).

18 J. Ostry, P. Loungani and D. Furceri (2016) 'Neoliberalism Oversold?', IMF Finance and Development 53(2), 38-41 https://www.imf.org/external/pubs/ft/fandd/ 2016/06/pdf/ostry.pdf (accessed 1 June 2020).

19 Metcalf (2017). 
Populist authoritarian political and economic governance globally have held out the carrot benefits of neoliberal austerity, and convinced the vulnerable that militant parochialism opposing globalist engagement is the essential context for enjoying 'trickle-down' by all true believers - no matter what glutinous material advantage is jealously protected by a tiny cadre of winners.

Conventional economists must share some of the blame for this state of affairs. ${ }^{20}$ In his article 'Blame Economists for the Mess We Are In', the author concluded,

Willful indifference to the distribution of prosperity over the last half century is an important reason the very survival of liberal democracy is now being tested by nationalist demagogues. I have no special insight into how long the rope can hold, or how much weight it can bear. But I know our shared bonds will last longer if we can find ways to reduce the strain. ${ }^{21}$

Hayek's vision of the market as a mind - as a mine of truth, has degenerated into a morass of transactional self-interest. Adam Smith's warning that the market as an autonomous sphere of human activity depended on individual virtue has gone unheeded, and we are left with a market of the anti-social. Neoliberalism has become Adam Smith without the ethical anxiety.

If markets are not seen as part of society or even subservient to it, ${ }^{22}$ but rather driving society as a whole; then in a neoliberal decline, humans will follow their own self-interest to wrestle with limited resources and scarce rewards, hamstrung by ever diminishing opportunities for competition, caused by the structural inequalities of the market/social. ${ }^{23}$ Where humans compete in a non-competitive market, then the measure of who and what is valuable becomes dependent on the power to determine and distort meanings, which are in turn held in the hands of the winners.

The analysis to follow does not work from such market visions; nor does it renounce, as did Hayek, responsibility outside the market for those social orders that can resist tyranny and exploitation, and ensure human dignity. Law can be one of these ordering agents, for good or ill. As Singer suggests in

20 B. Appelbaum (2019) 'Blame Economists for the Mess We Are In', New York Times https://www.nytimes.com/2019/08/24/opinion/sunday/economics-milton -friedman.html (accessed 1 June 2020).

21 Appelbaum (2019).

22 K. Polanyi (2001) The Great Transformation: The Political and Economic Origins of Our Time, Boston: Beacon Press.

23 Discussed in more detail later in the text, and in M. Findlay (2019) 'Regulatory Interface: Polanyi, the Market Social and Legal Agency', https://papers.ssrn.com/sol3/ papers.cfm?abstract_id=3372671 (accessed 1 June 2020). 
his defence of law following the subprime mortgage collapse in the USA and against the anti-regulation = freedom mythology:

The deeper truth is that laws designed to allow us to live together in harmony do not take away our liberty; they are what makes us free. This does not mean, of course, that all laws are good; some indeed take away our 'freedom'. Nor does it mean that liberals and libertarians agree on which laws are necessary to promote freedom. What it does mean is that promoting freedom requires a strategy other than 'removing government regulation'. It requires adopting appropriate regulations that promote the way of life that allows us to enjoy the liberties we cherish. That means we must define those liberties and choose the contours of our way of life in order to distinguish regulations that promote freedom from those that deny it. ${ }^{24}$

From the perspective of the pandemic, laws and regulations restricting movement and association, and prescribing mask wearing, have been represented by some us unconscionable violations of personal liberty and freedoms. The other view is that they promote and protect the personal and communal freedoms that health and safety bring, where life and death should be prioritised over self-determination. Asserting individuality, and thereby denying collective responsibility, delimits and degrades freedom for all.

In a humane reading of law, and its relationship with the market, market values are promoted when laws are adopted and enforced to ensure equal opportunity to participate in economic life. But because of the neoliberal capture of law and legal agency to service its pricing of human value only in market terms, law has largely lost this capacity to bulwark against market exploitation. Law is now the protectionist discourse of private property rights, a discourse which refuses to countenance property as social relations, ${ }^{25}$ preferring a linguistics of scarcity, exclusion and access only through rent.

Selective protectionism is a constant feature of the modern political and economic era, and one wherein law has predominated in securing the private property interests of the advantaged few. In his foreword to 'The Great Transformation', Joseph Stiglitz observed:

Truly free markets for labour or goods have never existed. The irony is that today [in 2000] few even advocate the free flow of labour, and while the advanced industrial countries lecture the less developed countries on the vices of protectionism and government subsidies, they have been more adamant in opening up markets in

\footnotetext{
24 J. Singer (2012) 'Subprime: Why a Free and Democratic Society Needs Law', Harvard Civil Rights - Civil Liberties Law Review 47(1), 146-67, at 144.

25 J. Singer (2000) Entitlement: The Paradoxes of Property, New Haven: Yale University Press.
} 
developing countries than in opening their own markets to the goods and services that represent the developing world's comparative advantage. ${ }^{26}$

What makes neoliberalism 'neo' is the move away from laissez-faire liberal market meanderings to the state actively organising for the benefit of the market economy, and little or nothing more. In this world of exclusionist, oligopolistic market economies, politics must essentially be submitted to an economic analysis. The lawmaker then optimises commodified market interests through pricing mechanisms and property rights protection regimes centred on discriminatory private property, not human dignity.

This book imagines a sustainable social space for accessible property relations beyond the current dominant market materialism; a public sphere where reasons are offered up and the reasons of others are contested. ${ }^{27}$ That space is more likely and possible through modern messaging platforms. BUT - while the internet has empowered and seemingly democratised that space, it has at the same time endangered aspirations for responsible messaging and dignified engagement. As Stephen Metcalf writes:

The internet is personal preference magnified by algorithms; a pseudo public space that echoes the voice already inside our head. Rather than a space for debate in which we make our way, as a society, towards consensus, now there is a mutual-affirmation apparatus banally referred to as a 'marketplace of ideas'. What looks like something public and lucid is only an extension of our pre-existing opinions, prejudices and beliefs, while the authority of institutions and experts has been displaced by the aggregative logic of big data ... The awesome utilities of digital technology aside, an earlier and more humanist tradition, which was dominant for centuries, had always distinguished between our tastes and preferences - the desires that find expression in the market - and our capacity for reflection on those preferences, which allows us to form and express values. ${ }^{28}$

The Internet, while largely de-commodified in developed countries, remains a form of monetising or politicising activity in under-developed countries, where access to the global network, to be at the 'forefront of the information revolution and global restructuring of capital' ${ }^{29}$ is heavily filtered. Again, law can have a powerful regulatory role in protecting the knowledge commons. What stands in the way of an egalitarian legal purpose is law's current spon-

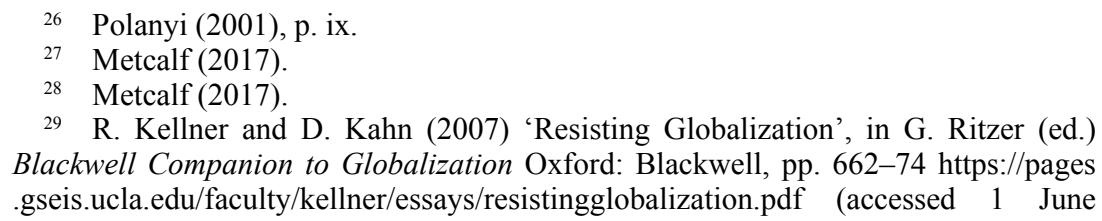
.gseis.ucla.edu/faculty/kellner/essays/resistingglobalization.pdf (accessed 1 June 2020). 
sorship by and within a market frame of exclusionary access and privileged rights and rewards.

Have the expressions of human subjectivity that populate the internet, no meaning without the market? Is society reconceived as a big market endangering a public life - to being no more than bickering over mere opinions, and leaving its intractable problems to the propaganda of the strongmen? Are the disenchanted rioting over unemployment and inequality, or over opportunities to buy and sell and participate in markets for fast cars, flash clothes and the next iPhone?

This book turns its gaze away from the myths against globalisation, and concealing the distortions, discrimination and dystopia that is the neoliberal residue, towards a possible role for law as a transformational agent which does not derive its authority from market functionality. Instead, we advocate a style of law and a role for legal agency which returns to its essential humanist ideology and represents a public spiritedness, repulsive to neoliberal self-obsession. As the electorate selects on whim, turns to policies drained of salience and without any explanatory scheme, relying on creatures of the neoliberal design; law has a new and urgent relevance to confront the absence of reason in self-determined market places, and to make coherent the anarchic forces which are currently running, or ruining the world. The confidence in such transformation grounds in the inevitability of law's re-invention, not only because global crisis challenges law's commodification, but as we look to a 'new normal' where values are reconsidered, then the role of law in a new social ordering will not simply be a market question. When social good has been reduced to 'the bottom line's sharp dealing', Cohen reflects, 'No big deal, except that the system that produces such rip-offs is ripe for the furies. ${ }^{30}$ In any transit from the pandemic's ravages there will be a 'time for law' but not as we have known it when commodification dehumanised legal services, and access to justice was on cost and not on pressing social need.

The argument to follow takes this form. Rather than conceding globalisation is a force for disorder and destabilising disruption in some ordained balance of global powers by:

- facilitating and producing resistance movements that create tension within the global framework and for international actors;

- increasing interconnectedness and interdependence which open up and activate new vulnerability to crises, and thereby

- tearing away the material security of last centuries' favoured middle-classes,

30 Cohen (2017). 
this argument prefers that globalisation is a vehicle for positive social transformation by:

- empowering communities to seek out more equitable consequences through healthy competition in the global framework of power dispersal;

- increasing interconnectedness and interdependence which in fact offers and sustains new and collaborative solutions, in turn not relying on

- idealised and distracting notions of democracy or utopian aspirations for participation and inclusion across the global community. Instead, within a dynamic of global engagement, law can facilitate targeted strategies of engagement (such as the economic empowerment of women) which go beyond political rhetoric, by employing a communitarian globalisation model with defined legal relationships, boundaries and outcomes.

However, the rehabilitation of globalisation through challenging its surrounding myths, worthy as that project might be, is not the limit of this enquiry. It follows that globalisation as a process for repudiating rather than serving the excesses of neoliberal exclusionism needs to be understood in new ways. I will dedicate a chapter of the book to re-imagining globalisation as a process of enabling the interconnection and inclusion which confounds exclusionist neoliberal market interests. A platform for this revision will be a critical evaluation of data-driven technologies in the management of big data by legal services. This focus is selected for more than a potential to attack law's current position in the service of neoliberal property arrangements. I will of course develop this critique and the motivations behind the AI push into law firm decision-making and work-force relationships. Such analysis will enable the identification of ways in which the AI revolution might be a cover for salvaging the neoliberal economic project. Out of this thinking, the argument will progress to briefly speculating how a radically revised form, frame and mission for legal service delivery can protect the globalised engagement project and its enhanced role in meeting, matching and replacing a degenerating neoliberal market world.

Artificial intelligence is advanced as the medium to restore growth to failing economies, to answer resource depletion, to reduce reliance on labour and capital in the achievement of productivity, to moderate the impacts of mass migration, to improve the mundane occupation of workers and even to remedy global warming. Whatever its potentials as a panacea for global crises or local anxieties, there are obvious synergies between what big data and algorithm-driven technologies represent for market profitability, and neoliberal exclusionist market agendas.

Touching on the legal ecosystem and what it offers for a new way of lawyering and potential greater access to legal services, rather than profit maximisa- 
tion for the few through labour rationalisation and elite market expansion, the analysis will say something about:

- $\mathrm{AI}$ as a social good, and not a lifeline for neoliberal market sustainability;

- the enhancement of globalisation through severing its tether to the neoliberal economic project;

- how law and legal service delivery will be transformed once their commodification in neoliberal market frames can be reversed;

- the manner in which legal regulation can assist in the diminution of neoliberal excess, the understanding of globalisation as a process of social engagement and emancipation, and responsibilise new market forms that are and will be more reliant on data applications.

Law is a language of markets and market elites. That message must change if law's regulatory relevance is not to be another casualty of neoliberal market failure. The message that transformed law needs to broadcast is social good replacing exclusionist wealth creation - a message of regulatory practice, not promise.

At the other end of the work-life chain with post-human technologising, ${ }^{31}$ workers in platform economies (and their customers) operate in largely lawless ecosystems, where regulations fail to protect individual dignity, and to control the flow of secondary data which commodifies human experience without human accountability (see Chapter 7). Is this a natural consequence of a globalised labour force and disconnecting the capitalist from the social means of production? Or is it the inevitable transformation of human identity and a re-conception of the environment of existence which transhumanism advocates?

The answer lies in a flicker of life offered to neoliberalism through the revolution of AI technologies and big data as the imagined panacea for failing economic growth ${ }^{32}$ and toxic socio-demographics. ${ }^{33} \mathrm{AI}$ and big data come with exponential perceived and actual social risks for a world already assailed by an

31 T. Rutsky (2018) 'Technological and Posthuman Zones', Critical Posthumanism https://criticalposthumanism.net/technological-and-posthuman-zones/ (accessed 1 June 2020).

32 Accenture (2019) 'Artificial Intelligence is the Future of Growth', https://www .accenture.com/sg-en/insight-artificial-intelligence-future-growth (accessed 1 June 2020).

33 M. Findlay and S.W. Lim (2014) Regulatory Worlds: Cultural and Social Perspectives When North Meets South, Cheltenham, UK and Northampton, Mass., USA: Edward Elgar, p. 156. 
anxiety-fomenting pace of change.$^{34}$ However, the big data users (and abusers) and the AI industry leaders are championing a single regulatory model with distinct neoliberal synergies - end-user, top-down ethical compliance. ${ }^{35}$ And the version of ethics expounded in this wave is individualist, libertarian and Kantian. Critics have suggested that industry has captured the state's regulatory position and momentum by painting ethics and public private partnerships as the dominant modes, and the state has acquiesced because it accepts the neoliberal argument that regulation (sharp or interventionist) will slow the market. ${ }^{36}$ In true neoliberal exclusionist style, the regulatory responsibility is left in the hands of the wealth generators, who are also the greatest offenders of data breach and mismanagement, ignoring the essentials of accountable risk minimisation, cost or no cost. ${ }^{37}$

$\mathrm{AI}$ and big data are now as emblematic of globalisation as was the Internet 30 years back. Being a framework for social, political and economic interchange, globalisation is taken as a given with modern means of communication, and technological advance. Therein is reason enough for populist attack and neoliberal gas-lighting.

Globalisation is a process for message delivery and is not the message. But globalisation and its message have been captured by the neoliberal economic growth model, which employs the communication facility of globalisation and the internet to advance discriminatory interests. More accurately, the criticism does not lie with either globalisation or the Internet, but with the economic model that is marketed to produce abundance for some, but does so at the expense of equitable outcomes.

Globalisation and the internet have massively facilitated the exclusionist commodification of property, and now of data, as they have more recently enabled grass-roots resistance against commodification and its exclusionary

34 J. Bryson (2019) 'The Past Decade and Future of AI's Impact on Society', in Towards a New Enlightenment? A Transcendent Decade, Madrid: Turner, pp. 127-59 https://www.bbvaopenmind.com/wp-content/uploads/2019/02/BBVA-OpenMind -book-2019-Towards-a-New-Enlightenment-A-Trascendent-Decade-3.pdf (accessed 2 June 2020).

35 T. Hagendorff (2020) 'The Ethics of AI Ethics: An Evaluation of Guidelines', Minds and Machines 30, 99-120.

36 R. Ochigame (2019) 'The Invention of Ethical AI: How Big Tech Manipulates Academia to Avoid Regulation', The Intercept https://theintercept.com/2019/12/20/ mit-ethical-ai-artificial-intelligence/ (accessed 2 June 2020); M. Findlay and J. Seah (2020) 'An Ecosystem Approach to Ethical AI and Data Use: Experimental reflections', SMU Centre for AI \& Data Governance Research Paper No. 2020/03 https://ssrn . com/abstract=3597912 or https://ssrn.com/abstract=3597912 (accessed 25 July 2020).

37 Findlay and Seah (2020). 
consequences for data access and property sharing. ${ }^{38} \mathrm{AI}$ and big data represent and rely on globalisation to produce phenomenal change in world lifestyles, for social good and evil. Remembering that the vast majority of the world's population know little or nothing of the benefits of globalisation, it is the facility for discrimination and disempowerment, rather than engagement itself which must be challenged.

However, with each novel (or predictably recurrent) global crisis, the enemies of engagement are quick to attack globalisation as the cause instead of a potential remedy. In an article entitled 'Outbreak Underscores Pitfalls of Globalisation', the author suggests that deficiencies in globalisation could be held responsible for the spread of the COVID-19 virus. ${ }^{39}$ However, the article jumps from speculating on the disruption a pandemic can cause to the global supply chain (which the neoliberal economist would identify as essential for contemporary multi-national commerce) to denouncing migration waves and open borders in the language of nationalist politics. What can be drawn from attributing world health endangerment to globalised engagement is the paradox that we want the wealth creation stimulus from global trade interconnections, while celebrating nationalist protectionism and restrictions on the human impulse to travel. It is a bit like stuffing your face with mono-cultural fast food while spluttering profanities against the 'dangerous other'.

This book starts out to unmask the critique of globalisation and direct the resistance against neoliberalist agendas/messages that are being propagated through these frames. In addressing the disaffection with globalisation, the book will rehabilitate globalisation not as it is advocated by neoliberal market forces that falsely claim its potential for universal abundance. What needs to be argued for is not a blanket rejection of everything that globalisation entails, but a reimagination of who globalisation is meant to benefit. In the call for a transformation in the economic order advanced through globalisation, the integration and inclusion offered by globalisation as avenues of resistance to the old and communication with the new, requires orderly and refreshed social bonding. ${ }^{40}$ Law can provide a vibrant facility for the transition of the market/ social away from neoliberal exclusionism and towards participatory social good, if it acts as a communal rather than a commodity resource.

Findlay (2017), chaps 3 and 5.

39 P. Goodman (2020) 'A Global Outbreak Is Fueling the Backlash to Globalization', New York Times https://www.nytimes.com/2020/03/05/business/coronavirus-globalism .html (accessed 2 June 2020).

40 Findlay (2017), chap. 5. 
Returning to Stiglitz on Polanyi and a dimension of the transformation for which this book argues:

The advocates of the neoliberal Washington consensus emphasise that it is government interventions [into the market] that are the source of the problem; the key to transformation is 'getting prices right' and getting the government out of the economy through privatization and liberalization. In this view, development is little more than the accumulation of capital and improvements in the efficiency with which resources are allocated - purely technical matters. This ideology misunderstands the nature of the transformation itself - a transformation of society, not just of the economy, and a transformation of the economy that is far more profound than their simple prescriptions would suggest. Their perspective represents a misreading of history ... all too often privatization, liberalization and even macro-stabilisation have been treated as the objectives of reform ... But all too often no scorecard was kept on the number of individuals who were pushed into poverty, or the number of jobs destroyed versus those created, or on the increase in violence, or on the increase in the sense of insecurity or the sense of powerlessness. ${ }^{41}$

Is this process of dispossession, alienation and anxiety exacerbated by living in a digital world? If so, from the global to the digital, what would we want the law to protect? The answer to that question takes us back to an essential consideration of what is 'the personal' for which liberty is offered or denied, and to whom dignity is accorded or excluded. In a review of Jia Tolentino's new book Trick Mirror: Reflections on Self-Delusion, the observation is made:

Tolentino considers the modern self not as something to be exposed or exploited, like a mineral deposit, but as something to construct and critique. She finds her subject in what she calls 'spheres of public imagination' ... [however] overwhelmed by the injustice she sees around her, she reflects on her own 'ethical brokenness'. 'I have felt so many times that the choice of this era is to be destroyed or to morally compromise ourselves in order to be functional - to be wrecked, or to be functional for reasons that contribute to the wreck.' You can refuse on principle to use ridesharing apps or rent from Airbnb, but you might end up panicked and sweating on another broken-down subway train ... these are distinctly millennial sentiments, the complaints of a generation that has come into political consciousness only after investing so much in false meritocratic promises ... 'I am complicit no matter what I do' can be both a realization reached after rigorous self-reckoning and something like a dead end. Just because you can't fix climate change with your own consumer choices doesn't mean there's nothing to be done. ${ }^{42}$

41 Polanyi (2001), pp. xiv-xvi.

42 M. Doherty (2019) 'Jia Tolentino on the "Unlivable Hell" of the Web and Other Millennial Conundrums', The New York Times https://www.nytimes.com/2019/08/04/ books/review/jia-tolentino-trick-mirror.html (accessed 2 June 2020). 
In a disillusioned post-neoliberal digital world, where can law position itself as a remedy for decline and a path out of alienation? As Singer suggests, and I intend to confirm:

We have outlawed feudalism, slavery, patriarchy, apartheid, and discriminatory denial of access to the market ... We seek law not because we are irrational or weak or because we do not value liberty but because we demand to be treated like human beings and we seek to be treated by others as they would want to be treated ... We should not demand liberties for ourselves that we would deny others. ${ }^{43}$

The horror of racial discrimination in the USA (and worldwide) is presently forcing protest onto the streets risking a pandemic second wave. Attacks on populist world ordering are advancing on all sides with a passion out of frustration that is no longer contained by baton charges, tear gas and rubber bullets. The anxiety mongers call for deploying the military in civil unrest. The economic titans push for a rush back to work as if pandemic health risk is a trade-off for business as usual. In all the pandemonium where is the call for law? Where are the lawyers? Where are the voices for justice giving direction away from violent transition? There are answers to these questions in what follows - but answers that will have no meaning if they remain words on a page.

A unifying metaphor throughout what follows is the mask, and masking functions. Masks conceal and reveal, they hide meaning, while parading alternate meanings sometimes true, often false. Most of all masks represent a vehicle for the audience to be mystified by fantasy, to avoid harsh realities and live comfortably with paradox. As the analysis will reiterate throughout, neoliberalism is ill-liberal. Democracy regularly descends into demagoguery. Free markets are enslaved in a global economic model that bars access to the powerless. The masks go on and on. As with masks in the Noh tradition, a shaded movement from the actor behind the mask will bring about a subtle deflection of emotion and a repositioning of personality. It will be argued that for too long, as a servant of neoliberalism, law has operated as a relentless mask between the needs and desires of society, and the harsh realities of market wealth creation. In later chapters the opportunities for deflection and repositioning behind law's masking function will lead to an inevitable unmasking of neoliberalism and globalisation, delivering a denouement unlike that which mystery plays, dark satires or tragicomedies that act out the old normal would inevitably conclude.

43 Singer (2012), p. 167. 